Received 00th January 20xx,

Accepted 00th January 20xx DOI: $10.1039 / \times 0 \times x 00000 x$

\title{
Selective carbene transfer to amines and olefins catalyzed by ruthenium phthalocyanine complexes with donor substituents
}

\author{
Lucie P. Cailler, ${ }^{a}$ Andrey P. Kroitor, ${ }^{b}$ Alexander G. Martynov, ${ }^{* b}$ Yulia G. Gorbunova, ${ }^{* b, c}$ and Alexander \\ B. Sorokin*a
}

\begin{abstract}
Electron-rich ruthenium phthalocyanine complexes were evaluated in carbene transfer reactions from ethyl diazoacetate (EDA) to aromatic and aliphatic olefins as well as to a wide range of aromatic, heterocyclic and aliphatic amines for the first time. It was revealed that ruthenium octabutoxyphthalocyanine carbonyl complex $\left[(\mathrm{BuO})_{8} \mathrm{Pc}\right] \mathrm{Ru}(\mathrm{CO})$ is the most efficient catalyst converting electron-rich and electron-poor aromatic olefins to cyclopropane derivatives with high yields (typically 80-100 \%) and high TON (up to 1000) under low catalyst loading and nearly equimolar substrate/EDA ratio. This catalyst shows a rare efficiency in the carbene insertion to amine $\mathrm{N}-\mathrm{H}$ bonds. Using a $0.05 \mathrm{~mol} \%$ catalyst loading, a high amine concentration $(1 \mathrm{M})$ and 1.1 eq. of EDA, a number of structurally divergent amines were selectively converted to monosubstituted glycine derivatives with up to quantitative yields and turnover numbers achieving 2000. High selectivity, large substrate scope, low catalyst loading and practical reaction conditions place $\left[(\mathrm{BuO})_{8} \mathrm{Pc}\right] \mathrm{Ru}(\mathrm{CO})$ among the most efficient catalysts for the carbene insertion to amines.
\end{abstract}

\section{Introduction}

In recent years, catalytic carbene transfer reactions have emerged as powerful synthetic approach in organic chemistry. ${ }^{1}$ Due to high versatility of this synthetic strategy involving metal carbene complexes, a large range of elaborated compounds can be prepared via cyclopropanation of olefins and carbene insertion into $\mathrm{C}-\mathrm{H}, \mathrm{N}-\mathrm{H}, \mathrm{O}-\mathrm{H}$ and other bonds. Among different transition metal complexes, the porphyrin complexes of iron, ${ }^{2}$ iridium, ${ }^{3}$ ruthenium, ${ }^{4}$ osmium, ${ }^{5}$ rhodium $^{6}$ and cobalt $^{7}$ exhibit particularly interesting catalytic properties in these reactions. ${ }^{8}$ Since a seminal work by Arnold and co-workers on the efficient application of engineered cytochrome P-450 for the cyclopropanation of olefins, ${ }^{9}$ extremely efficient and versatile bio-catalysts for cyclopropanation and carbene insertion into $\mathrm{N}$ $\mathrm{H}, \mathrm{C}-\mathrm{H}, \mathrm{S}-\mathrm{H}, \mathrm{Si}-\mathrm{H}$ and $\mathrm{B}-\mathrm{H}$ bonds have been developed by a direct evolution of several hemoproteins bearing iron porphyrin active site. ${ }^{10}$ Alternative approach to artificial metalloenzymes which are highly efficient in carbene transfer reactions was proposed by Hartwig and co-workers. ${ }^{11,12}$ Reconstituted cytochrome P450 enzyme CYP119 containing an iridium porphyrin in place of iron site catalyzed insertion of carbenes into $\mathrm{C}-\mathrm{H}$ bonds with up

\footnotetext{
aniv. Lyon, Université Claude Bernard Lyon 1, CNRS, IRCELYON,

2 av. A. Einstein, 69626 Villeurbanne, France

E-mail: alexander.sorokin@ircelyon.univ-lyon1.fr

b. A. N. Frumkin Institute of Physical Chemistry and Electrochemistry,

Russian Academy of Sciences,

Leniskii pr., 31, bldg.. 4, 119071 Moscow, Russia

c. E-mail: martynov.alexandre@gmail.com

d. N. S. Kurnakov Institute of General and Inorganic Chemistry,

Russian Academy of Sciences,

Leniskii pr., 31, 11991 Moscow, Russia

E-mail: yulia@igic.ras.ru

Electronic Supplementary Information (ESI) available: [Experimental details for catalytic reactions, characterization of catalysts and products]. See DOI: $10.1039 / x 0 x x 00000 x$
}

to $98 \%$ e.e., 35000 turnovers and $2550 \mathrm{~h}^{-1}$ turnover frequency ${ }^{11}$ and perform site-selective functionalization of $\mathrm{C}\left(\mathrm{sp}^{3}\right)$ - $\mathrm{H}$ bonds. ${ }^{12}$ Myoglobin reconstructed with ruthenium mesoporphyrin IX catalyzed cyclopropanation of vinyl anisole and aniline $\mathrm{N}-\mathrm{H}$ insertion with 350 and 520 turnover numbers, respectively. ${ }^{13}$ All these examples demonstrate that efficient catalysts for carbene transfer reactions can be achieved by the appropriate variation of the transition metal and supporting ligands. In quest for new carbene transfer catalysts, the reactivity of several complexes supported by non-heme ligands has been evaluated. ${ }^{14}$ It should be noted that related porphyrinoid complexes such as corroles, ${ }^{15}$ phthalocyanines, ${ }^{16}$ porphyrazines ${ }^{17}$ have been still under-investigated in carbene transfer reactions as compared to porphyrin complexes despite their promising catalytic properties in these reactions. For instance, Aviv and Gross showed superior catalytic activity of iron corroles in the largescope carbene insertion to the amine $\mathrm{N}-\mathrm{H}$ bonds under practical reaction conditions ( 0.1 mol\% catalyst loading, single addition of reagents under air) with high product yields within short reaction time. This high catalytic efficiency of iron corroles suggests that other over-looked porphyrin-like complexes deserve a more careful evaluation in the carbene transfer reactions.

In our ongoing project on the investigation of the catalytic properties of phthalocyanine complexes in cyclopropanation and carbene insertion into $\mathrm{X}-\mathrm{H}$ bonds, ${ }^{18}$ we decided to evaluate ruthenium phthalocyanine complexes for following reasons. First, their ruthenium porphyrin counterparts have been shown to catalyze cyclopropanation of olefins with high turnover frequencies via the formation of metal carbene complexes using diazo compounds as carbene precursors. ${ }^{4}$ Their reactivity was influenced by the nature of the porphyrin substituents and by the presence and nature of axial ligand(s). ${ }^{4 a}$ Metal carbene intermediates can react either with olefins to form cyclopropyl derivatives or with diazo precursors, e.g., with ethyl 
diazoacetate (EDA) to generate diethyl maleate (DEM) and diethyl fumarate (DEF). To limit the formation of these side EDA dimerization products occurring with most of metal complexes, the reactions are often performed using an excess of substrate. Although in the presence of limiting amount of EDA a higher selectivity in carbene insertion product can be achieved, the yields based on substrate can be very low when using the substrate/carbene precursor ratio of $2: 1,^{4 a, 4 d} 5: 1,{ }^{14 a, 19,20}$ $10: 1^{2 a, 15 c}$ or even $20: 1 .^{2 c}$ The reaction selectivity can be also improved using slow addition of diazo compound to the reaction mixture by syringe pump.

Compared to cyclopropanation reactions, the $\mathrm{N}-\mathrm{H}$ carbene insertion to amines catalyzed by ruthenium complexes have been less investigated. ${ }^{21,22}$ Simonneaux et al. reported the activity of (TMP)Ru(CO) (TMP = tetramesitylporphyrin) in intermolecular carbene $\mathrm{N}-\mathrm{H}$ insertion to aryl and alkylamines with $63-81 \%$ yields based on EDA. Because of strong coordination of ruthenium center with amines, a mixture of EDA and amine in 1:1.5 ratio was slowly added over $2.5 \mathrm{~h}$ to catalyst solution and up to $18 \mathrm{~h}$ were necessary to complete reactions. ${ }^{21}$ Che and co-workers published the carbene insertion into $\mathrm{N}-\mathrm{H}$ bonds of primary arylamines in aqueous media with water soluble glycosylated ruthenium porphyrin. ${ }^{22}$ Using a 1:2 EDA/amine ratio with 1 mol\% catalyst loading allowed avoiding complex poisoning and $76-91 \%$ yields of $\alpha$-aminoacid derivatives were obtained after $10 \mathrm{~h}$. This protocol was successfully applied to alkylate the $\mathrm{N}$-terminus of peptides and to mediate $\mathrm{N}$-terminal modification of proteins. ${ }^{22}$

Along with ruthenium porphyrins, a large range of different ruthenium complexes were shown to be effective cyclopropanation catalysts in combination with diazo compounds. ${ }^{23}$ While mononuclear ruthenium phthalocyanines (RuPc) have been mainly used as oxidation catalysis, ${ }^{24 a}$ their evaluation in carbene transfer reactions has been limited by only one study of cyclopropanation of olefins. ${ }^{16 a}$ Among a range of metal phthalocyanine complexes studied in cyclopropanation of styrene, $\mathrm{Ru}^{\text {II } \mathrm{PcF}_{16}}$ ( $\mathrm{PcF}_{16}=$ hexadecafluorophthalocyanine) showed the highest product yields achieving $80 \%$ with catalyst:styrene:EDA ratio of 1:500:750 after $4 \mathrm{~h}$ at $25^{\circ} \mathrm{C}$ upon slow EDA addition over $2 \mathrm{~h}$. Cyclopropanation of seven styrene derivatives resulted in lower products yields with 3.2:1 - 5.8:1 trans/cis ratios. Two examples of intramolecular cyclopropanation of diazo compounds bearing aromatic and aliphatic olefin fragments were also provided. Noteworthy, the $\left[\mathrm{Ru}^{\mathrm{III}} \mathrm{Pc}\right] \mathrm{Cl}$ complex was less efficient in styrene cyclopropanation to afford a $59 \%$ product yield with a 1.9:1 trans/cis selectivity. ${ }^{16 a}$ This study suggests that the catalytic efficiency depends on the properties of the phthalocyanine ligand, in particular, on the nature of substituents determining its electronic properties. ${ }^{25}$ While metal phthalocyanine complexes are prominent catalysts for many reactions, ${ }^{24}$ their applications in catalytic carbene transfer reactions are surprisingly scarse. ${ }^{16,18}$ Motivated by remarkable catalytic properties of single-atom bridged binuclear phthalocyanine complexes, ${ }^{24 b-24 e}$ we have recently studied $\mu$-carbido diruthenium phthalocyanine complex in combination with EDA in cyclopropanation of aromatic olefins and in carbene insertion to aromatic and aliphatic amines. ${ }^{18 \mathrm{~b}}$ At $0.1 \mathrm{~mol} \%$ catalyst loading and 1.2:1 EDA/substrate ratio these reactions occurred with turnover numbers of $680-1000$ and 580-1000, respectively, at $90^{\circ} \mathrm{C}$. Hence, it would be of interest to probe reactivity of the mononuclear counterpart. Herein, we report the evaluation of three mononuclear ruthenium phthalocyanine complexes (Figure 1 ) in cyclopropanation of a large range of styrene derivatives and aliphatic olefins as well as carbene insertion into $\mathrm{N}-\mathrm{H}$ bonds of aromatic, aliphatic and heterocyclic amines.

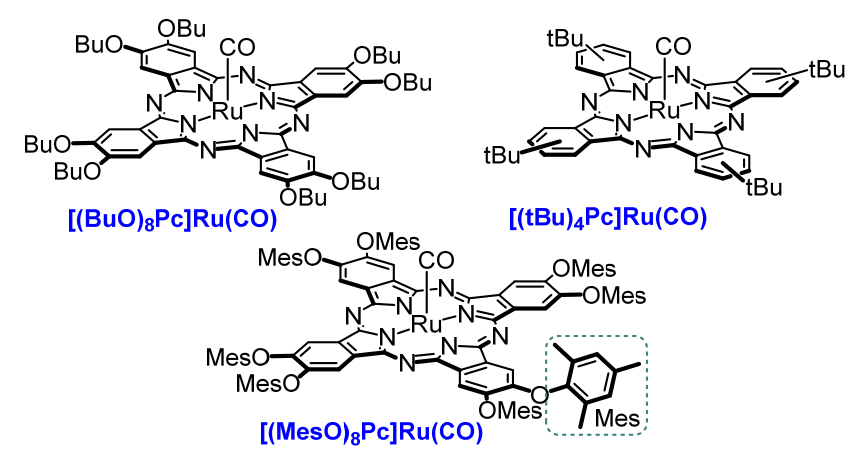

Figure 1. Structures of complexes evaluated in carbene transfer reactions.

\section{Results and Discussion}

\section{Cyclopropanation of olefins}

Three carbonyl ruthenium phthalocyanine complexes with different substitution patterns were prepared and characterized as previously described (Figure 1). ${ }^{18 b, 26}$ Their activity was initially evaluated in the cyclopropanation of styrene by EDA (Table 1). To favor cyclopropanation reaction over competing dimerization of EDA to diethyl fumarate and diethyl maleate, one eq. of EDA was added to a $1 \mathrm{M}$ styrene solution containing $1 \mathrm{mM}$ catalyst during $2 \mathrm{~h}$ under argon at 25 ${ }^{\circ} \mathrm{C}$. Among the three complexes, $\left[(\mathrm{BuO})_{8} \mathrm{Pc}\right] \mathrm{Ru}(\mathrm{CO})$ was found to provide a higher yield of cyclopropanation product and limited amount of side products owing to EDA dimerization. Thus, the $\left[(\mathrm{BuO})_{8} \mathrm{Pc}\right] \mathrm{Ru}(\mathrm{CO})$ complex has been further studied to evaluate a scope of olefin cyclopropanation using 1.2 eq. of EDA as carbene precursor. The reaction was successfully extended to styrene derivatives bearing electron-donating or electron-

Table 1. Cyclopropanation of styrene by EDA catalyzed by ruthenium phthalocyanines. ${ }^{a}$

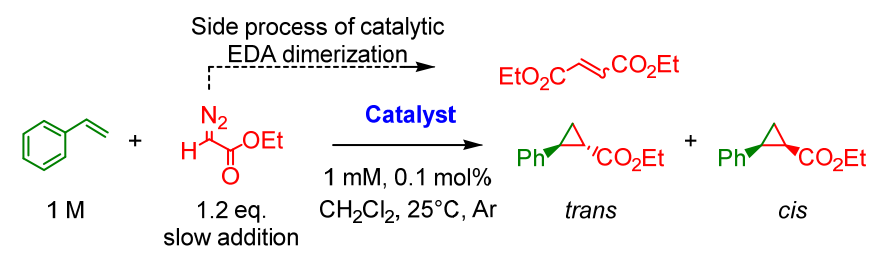




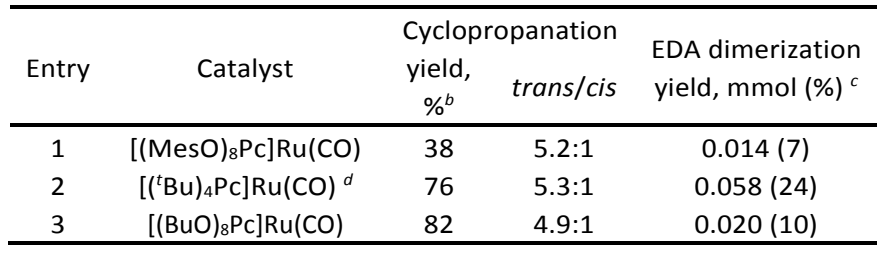

${ }^{a}$ Conditions: styrene $(0.4 \mathrm{mmol})$, catalyst $(0.1 \mathrm{~mol} \%)$, EDA (slow addition of $0.4 \mathrm{mmol}$ as a $2 \mathrm{M}$ solution in $\mathrm{CH}_{2} \mathrm{Cl}_{2}, 0.10 \mathrm{~mL} / \mathrm{h}$, addition time $-2 \mathrm{~h}$ ), $\mathrm{CH}_{2} \mathrm{Cl}_{2}$ $\left(0.4 \mathrm{~mL}\right.$ ), argon, $25^{\circ} \mathrm{C}, 2.5 \mathrm{~h} .{ }^{b}$ Yields determined by ${ }^{1} \mathrm{H}$ NMR are based on styrene. ${ }^{c}$ Yields of DEM and DEF were determined by ${ }^{1} \mathrm{H}$ NMR (EDA amount consumed for dimerization, \%). ${ }^{d} 0.48 \mathrm{mmol}$ of EDA.

withdrawing substituents. A large range of olefins was typically converted to corresponding cyclopropyl derivatives with 83-100 $\%$ yields (Table 2 ).

Table 2. Substrate scope for the cyclopropanation of styrene derivatives by EDA catalyzed by $\left[(\mathrm{BuO})_{8} \mathrm{PC}\right] \mathrm{Ru}(\mathrm{CO}){ }^{a}$

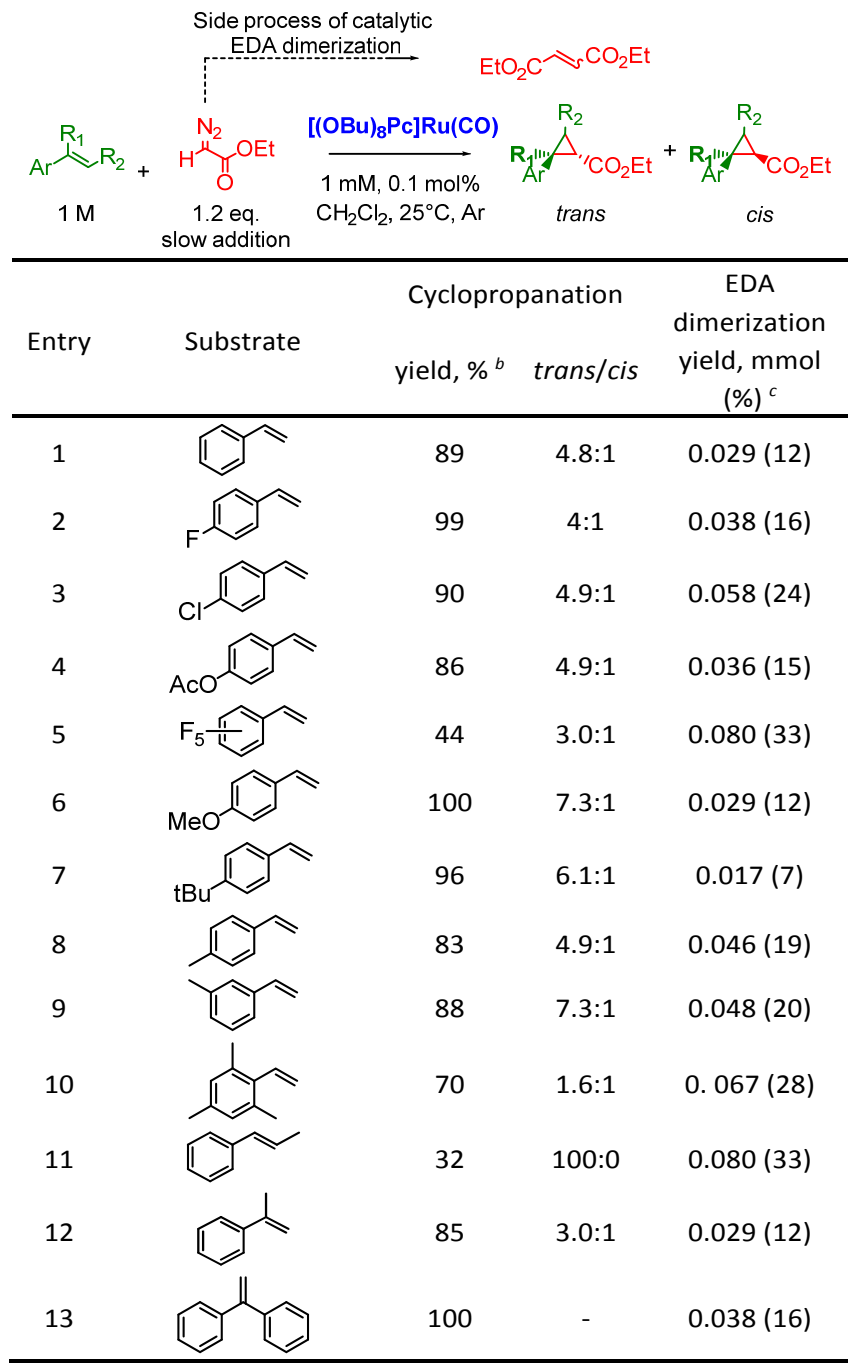

${ }^{a}$ Conditions: olefin $(0.4 \mathrm{mmol})$, catalyst $(0.1 \mathrm{~mol} \%)$, EDA (slow addition of $0.48 \mathrm{mmol}$ as a $2 \mathrm{M}$ solution in $\mathrm{CH}_{2} \mathrm{Cl}_{2}, 0.10 \mathrm{~mL} / \mathrm{h}$, addition time $-2 \mathrm{~h}$ ), $\mathrm{CH}_{2} \mathrm{Cl}_{2}$ $(0.4 \mathrm{~mL})$, argon, $25^{\circ} \mathrm{C}, 2.5 \mathrm{~h} .{ }^{b}$ Yields determined by ${ }^{1} \mathrm{H}$ NMR are based on olefin. ${ }^{c}$ Yields of DEM and DEF were determined by ${ }^{1} \mathrm{H}$ NMR (EDA amount consumed for dimerization, \%).
Only very electron-deficient pentafluorostyrene afforded a moderate cyclopropanation yield of $44 \%$ (Table 2, entry 5 ). The cyclopropanation reaction is sensitive to steric factor. The presence of the ortho methyl substituents in 2,4,6trimethylstyrene led to a $70 \%$ product yield (Table 2, entry 10). Methyl group of trans- $\beta$-methylstyrene strongly influenced on the selectivity to provide only trans isomer but the yield dropped to $32 \%$ (Table 2, entry 11). On the other hand, the presence of methyl or phenyl group in the $\alpha$-position of styrene vinyl group does not hinder the reactivity and results in the product yields of 85 and $100 \%$, respectively (Table 2, entries $12,13)$. These results are in line with a late transition state typical of ruthenium complexes supported by electron-rich macrocycles. Indeed, a trans/cis ratio observed with $\left[(\mathrm{BuO})_{8} \mathrm{Pc}\right] \mathrm{Ru}(\mathrm{CO})(4.9: 1-7.3: 1)$ is in general higher than that obtained with the electron-poor [RuPcF 16$]\left(3.2: 1\right.$ - 5.8:1). ${ }^{16 a}$ For instance, cyclopropanation of aniline and $p$-methoxyaniline by $\left[(\mathrm{BuO})_{8} \mathrm{Pc}\right] \mathrm{Ru}(\mathrm{CO})$ and $\left[\mathrm{RuPcF}_{16}\right]$ proceeds with trans/cis ratios of 4.8/3.2 and 7.3/4.8, respectively. Interestingly, styrenes bering electron donating substituents undergo cyclopropanation with a higher trans:cis ratio. This trend is opposite to that previously published in case of ruthenium porphyrins. ${ }^{4 d}$

Aliphatic olefins having neighboring $\pi$-donating heteroatoms or double bonds are also amenable to cyclopropanation (Table 3).

Table 3. Cyclopropanation of aliphatic olefins by EDA catalyzed by $\left[(\mathrm{BuO})_{8} \mathrm{Pc}\right] \mathrm{Ru}(\mathrm{CO}){ }^{a}$

\begin{tabular}{|c|c|c|c|c|}
\hline \multirow{2}{*}{ Entry } & \multirow{2}{*}{ Substrate } & \multicolumn{2}{|c|}{ Cyclopropanation } & \multirow{2}{*}{$\begin{array}{c}\text { EDA } \\
\text { dimerization } \\
\text { yield, mmol } \\
(\%)^{c}\end{array}$} \\
\hline & & yield, $\%{ }^{b}$ & trans/cis & \\
\hline 1 & & 86 & $2.4: 1$ & $0.014(6)$ \\
\hline 2 & & $78,7^{d}$ & $\begin{array}{c}4: 1 \\
53: 30: 15: 1^{e}\end{array}$ & $0.048(20)$ \\
\hline 3 & & 26 & $2.1: 1$ & $0.178(74)$ \\
\hline 4 & & $4^{f}, 2^{g}$ & - & $0.228(95)$ \\
\hline 5 & & 0 & - & $0.240(100)$ \\
\hline
\end{tabular}

${ }^{a}$ Conditions: olefin $(0.4 \mathrm{mmol})$, catalyst $(0.1 \mathrm{~mol} \%)$, EDA (slow addition of $0.48 \mathrm{mmol}$ as a $2 \mathrm{M}$ solution in $\mathrm{CH}_{2} \mathrm{Cl}_{2}, 0.10 \mathrm{~mL} / \mathrm{h}$, addition time $-2 \mathrm{~h}$ ), $\mathrm{CH}_{2} \mathrm{Cl}_{2}$ $(0.4 \mathrm{~mL})$, argon, $25^{\circ} \mathrm{C}, 2.5 \mathrm{~h} .{ }^{b}$ Yields determined by ${ }^{1} \mathrm{H}$ NMR are based on olefin. ${ }^{\mathrm{C}}$ Yields of DEM and DEF were determined by ${ }^{1} \mathrm{H}$ NMR (EDA amount consumed for dimerization, \%). ${ }^{d}$ Dicyclopropanated product. ${ }^{e}$ Ratio of stereoisomers of dicyclopropanated product determines by GC-MS. ${ }^{f}$ Cyclopropanation product. ${ }^{g}$ Allylic $\mathrm{C}-\mathrm{H}$ insertion product.

n-Butylvinylether afforded a $86 \%$ yield of cyclopropanation product (Table 3, entry 1). Diene with conjugated double bonds, 2,3-dimethyl-1,3-butadiene, furnished both mono- and dicyclopropanation products with 78 and $7 \%$ yields, respectively (Table 3, entry 2). The cyclopropanation of allylbenzene resulted in a $26 \%$ yield (Table 3 , entry 3 ). Thus, the presence of aryl, vinyl or ether groups adjacent to the double bond favors its cyclopropanation due to stabilization of the partial positive charge developed in the late transition state at the $\alpha$-carbon 
atom of the olefin. ${ }^{[2 a]}$ Cyclopropanation of internal and branched olefins was inefficient most likely owing to a hindered approach of the double bond to the active carbene complex. Cyclohexene was cyclopropanated with only $4 \%$ yield whereas 2,3-dimethyl-2-butene did not react at all (Table 3, entries 4,5). The carbene insertion to the allylic $\mathrm{C}-\mathrm{H}$ bond of cyclohexene occurred with a $2 \%$ yield. In case of less reactive olefins, the products of EDA dimerization were formed with high yields. The aliphatic olefins exhibit in general a lower trans selectivity of cyclopropanation compared with styrene derivatives most probably due to the higher flexibility.

The scope of diazo compounds was also evaluated (Table 4). Butyl diazoacetate (BDA), ethyl diazophenylacetate (EDPA) and trimethylsilyl diazomethane (TMSD) were tested as carbene precursors in combination with $\left[(\mathrm{BuO})_{8} \mathrm{Pc}\right] \mathrm{Ru}(\mathrm{CO})$ for cyclopropanation of styrene.

Table 4. Cyclopropanation of styrene by different diazo carbene precursors catalyzed by $\left[(\mathrm{BuO})_{8} \mathrm{Pc}\right] \mathrm{Ru}(\mathrm{CO}) .^{a}$

\begin{tabular}{|c|c|c|c|c|}
\hline & $\begin{array}{l}\mathrm{N}_{2} \mathrm{OEt} \\
\text { EDA }\end{array}$ & & $\begin{array}{l}\mathrm{N}_{\mathrm{O}}^{\mathrm{N}_{2}} \mathrm{OEt} \\
\text { EDPA }\end{array}$ & $\begin{array}{l}\mathrm{N}_{2} \\
\mathrm{SiMe}_{3} \\
\text { TMSD }\end{array}$ \\
\hline \multirow{2}{*}{ Entry } & \multirow{2}{*}{ Diazo precursor } & \multirow{2}{*}{$\mathrm{T},{ }^{\circ} \mathrm{C}$} & \multicolumn{2}{|c|}{ Cyclopropanation } \\
\hline & & & yield, $\%^{b}$ & trans:cis ratio \\
\hline 1 & EDA & 25 & 89 & $4.8: 1$ \\
\hline 2 & $\mathrm{BDA}^{c, d}$ & 35 & 53 & 1.9:1 \\
\hline 3 & EDPA & 25 & traces & n.d. \\
\hline 4 & $\mathrm{TMSD}^{c, e}$ & 35 & traces & n.d. \\
\hline 5 & TMSD $^{f}$ & 70 & 69 & $1.6: 1$ \\
\hline
\end{tabular}

${ }^{a}$ Conditions: styrene $(0.4 \mathrm{mmol})$, catalyst $(0.1 \mathrm{~mol} \%), 0.48 \mathrm{mmol}$ of diazo compound was slowly added to reaction mixture as a $2 \mathrm{M}$ solution in $\mathrm{CH}_{2} \mathrm{Cl}_{2}, 0.10$ $\mathrm{mL} / \mathrm{h}$, addition time $-2 \mathrm{~h}), \mathrm{CH}_{2} \mathrm{Cl}_{2}(0.4 \mathrm{~mL})$, argon, $25^{\circ} \mathrm{C}, 2.5 \mathrm{~h} .{ }^{b}$ Yields determined by ${ }^{1} \mathrm{H}$ NMR are based on olefin. ${ }^{c}$ The reaction was set at $25^{\circ} \mathrm{C}$ for $2 \mathrm{~h}$ and then heated at $35^{\circ} \mathrm{C}$ overnight. ${ }^{d} \mathrm{~A} 15 \% \mathrm{BDA}$ solution in toluene was added over $2 \mathrm{~h}$ at $0.163 \mathrm{~mL} / \mathrm{h}$ rate. ${ }^{e} \mathrm{~A} 2 \mathrm{M}$ TMSD solution in hexane was added. ${ }^{f}$ Overnight.

The reaction tolerates the presence of bulky group at ester moiety. Butyl diazoacetate provided a $53 \%$ cyclopropanation yield with a 66:34 trans/cis ratio (Table 4, entry 2 ). In contrast, the presence of bulky phenyl group in ethyl diazophenylacetate prevented the efficient cyclopropanation of styrene. Trimethylsilyl diazomethane was not efficient at $35^{\circ} \mathrm{C}$ because of its electron-rich nature which makes a substrate nucleophilic attack at carbene species difficult. However, when the reaction was carried out at $70^{\circ} \mathrm{C}$, corresponding cyclopropanation products were obtained with $69 \%$ yield (Table 4, entry 5). Thus, among the diazo compounds tested, readily available EDA showed the most promising results in cyclopropanation of olefins and has been further evaluated in combination with $\left[(\mathrm{BuO})_{8} \mathrm{Pc}\right] \mathrm{Ru}(\mathrm{CO})$ in the reaction with amines.

\section{Carbene insertion to $\mathrm{N}-\mathrm{H}$ bonds of amines}

Under reaction conditions used for cyclopropanation of olefins (1 $\mathrm{M}$ substrate, $0.1 \mathrm{~mol} \%$ catalyst loading, $25^{\circ} \mathrm{C}$ ), the reaction of EDA with aniline was slow. Thus, the reaction conditions for carbene $\mathrm{N}-\mathrm{H}$ insertion were initially optimized using aniline as a reference substrate (Table 5 ).

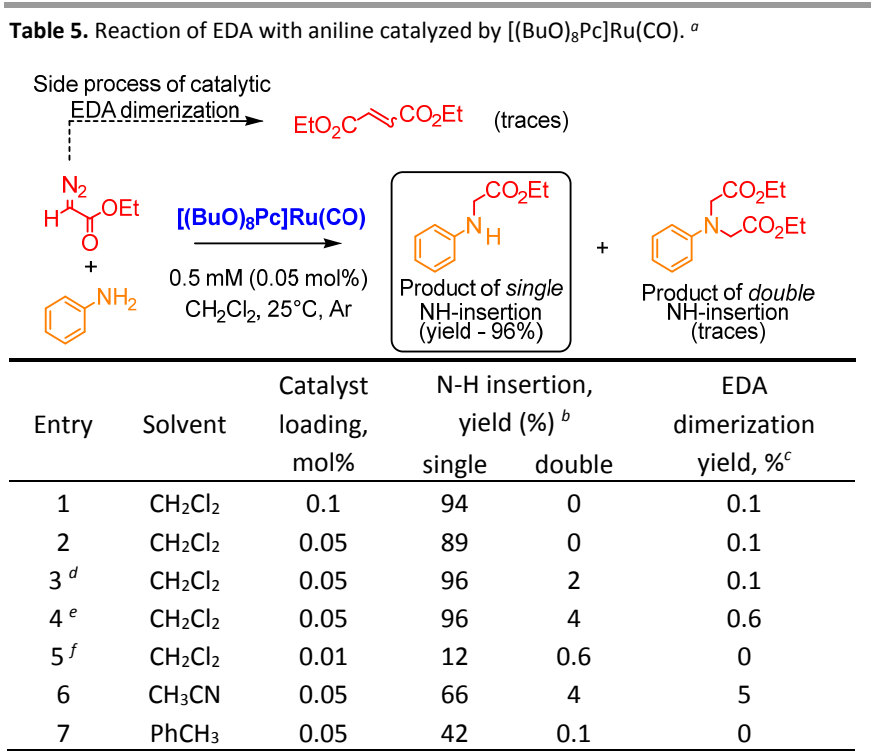

${ }^{a}$ Conditions: aniline (0.5 mmol), catalyst (0.05-0.1 mol\%), $\mathrm{CH}_{2} \mathrm{Cl}_{2}(0.5 \mathrm{~mL}), \mathrm{EDA}$ (0.5 $\mathrm{mmol}$ ), argon, $40^{\circ} \mathrm{C}, 1 \mathrm{~h} .{ }^{b}$ Yields determined by ${ }^{1} \mathrm{H}$ NMR are based on aniline. ${ }^{c}$ Yields of DEM and DEF determined by ${ }^{1} \mathrm{H}$ NMR are based on the starting EDA. ${ }^{d} 0.55 \mathrm{mmol}$ EDA. ${ }^{e} 1.1 \mathrm{mmol}$ of EDA was added. ${ }^{f}$ reaction time was $4 \mathrm{~h}$.

At a $1: 1$ aniline : EDA ratio, the reaction was completed within $1 \mathrm{~h}$ at $40^{\circ} \mathrm{C}$. Importantly, the dimerization of EDA did not compete with $\mathrm{N}-\mathrm{H}$ insertion and further reactions were carried out in a one-pot fashion without the need for slow EDA addition. Among the solvents tested, $\mathrm{CH}_{2} \mathrm{Cl}_{2}$ provided higher yield and selectivity to mono-insertion product whereas $\mathrm{CH}_{3} \mathrm{CN}$ and $\mathrm{PhCH}_{3}$ were less efficient (Table 5).

Noteworthy, the catalyst loading can be reduced from 0.1 to $0.05 \mathrm{~mol} \%$ without notable decrease of the product yield, from 94 to $89 \%$, respectively (Table 5 , entries 1,2 ). Using of 1.1 eq. EDA restored a high catalytic efficiency and the yield of $\mathrm{N}$ phenyl glycine ester achieved $96 \%$ corresponding to turnover number (TON) of 1920. Further decrease of the catalyst amount to $0.01 \mathrm{~mol} \%$ resulted in sharp drop of the yield to only $12 \%$ (TON=1200). Quite remarkably, $\left[(\mathrm{BuO})_{8} \mathrm{Pc}\right] \mathrm{Ru}(\mathrm{CO})$ shows excellent selectivity toward the product of single $\mathrm{N}-\mathrm{H}$ insertion and only trace amount of double insertion product $\mathrm{PhN}\left(\mathrm{CH}_{2} \mathrm{COOEt}\right)_{2}$ was detected (Table 5, entries 1-2). Even in the presence of 2 eq. EDA, a $96 \%$ yield of $\mathrm{PhNHCH}_{2} \mathrm{COOEt}$ was obtained along with only $4 \%$ of the double insertion product (Table 5, entry 4). Dichloromethane solvent provided much better results with respect to $\mathrm{CH}_{3} \mathrm{CN}$ and $\mathrm{PhCH}_{3}$ (Table 5, entries $6,7)$. Compared to cyclopropanation of olefins, a slow addition of EDA was not necessary because of the high selectivity to single $\mathrm{N}-\mathrm{H}$ insertion and almost quantitative product yield was obtained using 0.05 mol\% catalyst loading. Therefore, we have further explored a substrate scope using $0.05 \mathrm{~mol} \%$ $\left[(\mathrm{BuO})_{8} \mathrm{Pc}\right] \mathrm{Ru}(\mathrm{CO})$ in $\mathrm{CH}_{2} \mathrm{Cl}_{2}$ and 1.1 eq. EDA added in one portion at $40{ }^{\circ} \mathrm{C}$.

A wide range of aromatic, heterocyclic and aliphatic amines was selectively transformed to substituted glycine derivatives $\mathrm{RNHCH}_{2} \mathrm{COOEt}$ with $\mathrm{R}=$ aryl, heterocycle or alkyl group (Table 6). 
Table 6. Carbene $\mathrm{N}-\mathrm{H}$ insertion to aromatic, heterocyclic and aliphatic amines mediated by $\left[(\mathrm{BuO})_{8} \mathrm{Pc}\right] \mathrm{Ru}(\mathrm{CO})-\mathrm{EDA}$ system.

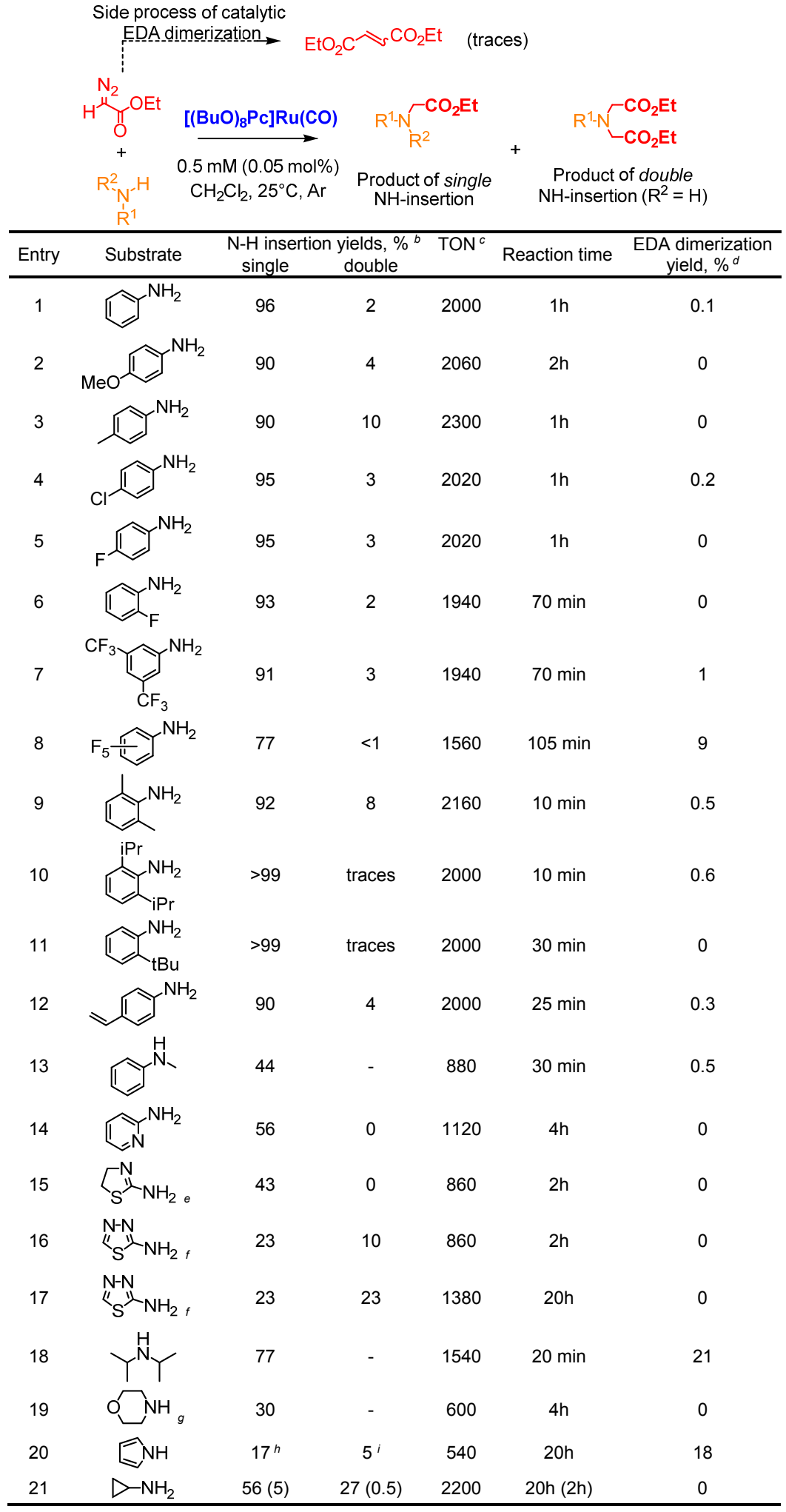

${ }^{a}$ Conditions: $0.5 \mathrm{mmol}$ amine, $0.55 \mathrm{mmol}$ EDA, $0.05 \mathrm{~mol} \%$ catalyst, $0.5 \mathrm{~mL} \mathrm{CH} 2 \mathrm{Cl}$, argon, $40^{\circ} \mathrm{C} .{ }^{b}$ Yields determined by ${ }^{1} \mathrm{H}$ NMR are based on amine. ${ }^{c}$ Total TON is defined as (mmol of single insertion product $+2 \times$ mmol of double insertion product) / mmol of catalyst. ${ }^{d}$ Yields of DEM and DEF determined by ${ }^{1} \mathrm{H}$ NMR are based on the starting EDA. ${ }^{e}$ unidentified product was additionally obtained with $9 \%$ yield. ${ }^{f}$ reaction mixture was diluted by factor $2 .{ }^{g} \mathrm{~A}$ mixture of morpholine (1 eq.) and EDA (1.1 eq.) was slowly added to catalyst solution. ${ }^{h}$ Product of $\alpha-\mathrm{C}-\mathrm{H}$ insertion, isolated yield. ' Product of double $2,5-\mathrm{C}-\mathrm{H}$ insertion, isolated yield. 
Aniline derivatives bearing electron-donating and electronwithdrawing groups afforded excellent yields of corresponding glycine derivatives, between 77 and $100 \%$ (Table 6, entries 112). In particular, anilines with electron-donor substituents in ortho position(s) provided quantitative product yields within short reaction time of 10-30 min (Table 6, entries 10,11) with turnover frequency (TOF) up to 200 cycles per minute. Even very electron- deficient pentafluoroaniline offered a yield of 77 $\%$ (Table 6 , entry 8 ). To the best of our knowledge, this is the highest yield of carbene $\mathrm{N}-\mathrm{H}$ insertion to such a difficult substrate. Noteworthy, $p$-aminostryrene, possessing both olefin and amino group as reactive sites, reacted selectively on its amino site (Table 6 , entry 12 ). Secondary $\mathrm{N}$-methylaniline was also amenable to $\mathrm{N}-\mathrm{H}$ insertion though with a lower yield of $44 \%$ (Table 6 , entry 13 ).

We next evaluated the reactivity of $\left[(\mathrm{BuO})_{8} \mathrm{Pc}\right] \mathrm{Ru}(\mathrm{CO})$ toward heteroaromatic amines. Amino-substituted pyridine, thiazoline and thiadiazole derivatives provided moderate product yields (23-56\%) and EDA was not completely consumed (Table 6, entries 14-17). No EDA dimerization was observed even if the reaction was allowed to run for a longer time.

Because of the strong coordination with metal complexes which inhibits catalytic site, in particular, when high amine/catalyst ratio is used, aliphatic amines are often considered as difficult substrates. Indeed, the reaction with cyclopropylamine was very slow providing only $5 \%$ yield after 2 h. Nevertheless, the cyclopropylamine was converted to monoand double $\mathrm{N}-\mathrm{H}$ insertion products with 56 and $27 \%$ yields, respectively, after $20 \mathrm{~h}$ (Table 6 , entry 21 ). Under standard conditions, conversions of 2-methoxyethylamine and morpholine were very low even after $20 \mathrm{~h}$ ( $12 \%$ yield of morpholine derivative). However, slow addition of the mixture of EDA and morpholine to the catalyst solution during $4 \mathrm{~h}$ allowed obtaining the glycine ester bearing morpholine group with a $30 \%$ yield (Table 6, entry 19). By contrast, diisopropylamine afforded a $77 \%$ yield of $\mathrm{N}-\mathrm{H}$ insertion within 20 min, most probably because of less strong coordination of this hindered amine to the metal center (Table 6, entry 18). Noteworthy, in this case the EDA dimerization byproducts were formed in $21 \%$ yield. This is the only example of the notable side carbene dimerization performed by the $\left[(\mathrm{BuO}){ }_{8} \mathrm{Pc}\right] \mathrm{Ru}(\mathrm{CO})$ - EDA system in the reaction with amines.

This observation shows that the properties of amine and its coordination to ruthenium center can play an important role in the outcome of the reaction. The amine nature may have impact on its coordination behavior toward the metal center and on its ability to attack the electrophilic metal-carbene intermediate thus influencing on the reaction selectivity for $\mathrm{N}$ $\mathrm{H}$ insertion vs carbene dimerization.

The reaction with pyrrole represents a particular case because of several possible reaction sites. The carbene group can be inserted to $\mathrm{N}-\mathrm{H}, \alpha-\mathrm{C}-\mathrm{H}$ or $\beta-\mathrm{C}-\mathrm{H}$ or cyclopropanate the double bond. In contrast to $\mathrm{N}$-protected pyrroles, functionalization of $1 \mathrm{H}$-pyrroles by metal-catalyzed carbene transfer have been rarely described involving copper based catalysts $^{27-29}$ and iron porphyrin complex. ${ }^{30} \mathrm{~A}$ recent detailed study by Pérez and co-workers showed that copper hydrotrispyrazolylborate complex (1 mol\% catalyst loading) catalyzed $\alpha-\mathrm{C}-\mathrm{H}$ functionalization of pyrroles by EDA using a $5: 1$ substrate/EDA ratio. ${ }^{27}$ Under reaction conditions used for the reaction with amines $\left(0.05 \mathrm{~mol} \%\left[(\mathrm{BuO})_{8} \mathrm{Pc}\right] \mathrm{Ru}(\mathrm{CO})\right.$ loading, 1.1 eq. EDA), pyrrole afforded two products after $20 \mathrm{~h}$ with $\mathrm{m} / \mathrm{z}$ values corresponding to single $(m / z=153)$ and double $(m / z=239)$ insertion of carbene into pyrrole (Table 6 , entry 20). These compounds were isolated by column chromatography with 17 and $5 \%$ yields, respectively, and were identified as ethyl pyrrole-2-acetate and diethyl pyrrole-2,5-diacetate on the basis of their ${ }^{1} \mathrm{H}$ and ${ }^{13} \mathrm{C}$ NMR spectra. ${ }^{27-29}$ (Scheme 1 ).

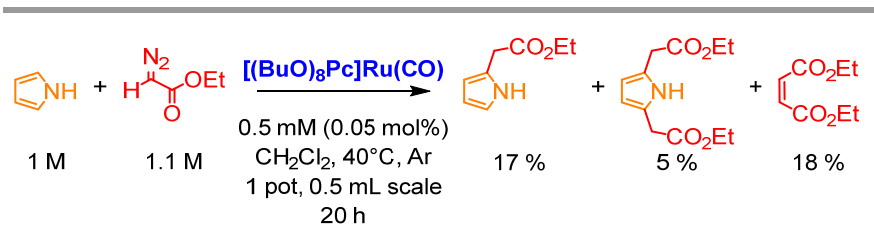

Scheme 1. Reaction of pyrrole with EDA catalyzed by $\left[(\mathrm{BuO})_{8} \mathrm{Pc}\right] \mathrm{Ru}(\mathrm{CO})$.

Thus, $\left[(\mathrm{BuO})_{8} \mathrm{Pc}\right] \mathrm{Ru}(\mathrm{CO})$ mediates the selective insertion of carbene derived from EDA into $\alpha-\mathrm{C}-\mathrm{H}$ bond of pyrrole. Although such a reactivity has been previously described, $27,28,30$ to our knowledge, a double $\alpha-\mathrm{C}-\mathrm{H}$ carbene insertion to pyrrole has not been reported.

Finally, to further confirm the practical character of this catalytic system, a gram scale reaction was carried out with 6 $\mathrm{mmol}$ of aniline and $6 \mathrm{mmol}$ of EDA in the presence of 0.05 mol\% $\left[(\mathrm{BuO})_{8} \mathrm{Pc}\right] \mathrm{Ru}(\mathrm{CO})$. N-Phenylglycine ethyl ester was obtained with $89 \%$ isolated yield $(0.95 \mathrm{~g})$.

\section{Conclusion}

This study represents the first detailed investigation of the catalytic properties of electron-rich ruthenium phthalocyanines in carbene transfer reactions. First, three complexes were evaluated in the cyclopropanation of styrene. The most electron-rich and the less hindered $\left[(\mathrm{BuO})_{8} \mathrm{Pc}\right] \mathrm{Ru}(\mathrm{CO})$ was the most efficient providing a $89 \%$ cyclopropanation yield using 1.2 eq. EDA with respect to olefin and 0.1 mol\% catalyst loading at $25^{\circ} \mathrm{C}$. The reaction scope was extended to aromatic olefins bearing electron-donating or electron-withdrawing substituents and to aliphatic olefins with conjugated double bonds or $\pi$-donating heteroatom. Using low catalyst loading and close to equimolecular substrate/EDA ratio, high cyclopropanation yields (typically $80-100 \%$ ) and high TON (up to 1000 ) have been achieved.

The $\left[(\mathrm{BuO})_{8} \mathrm{Pc}\right] \mathrm{Ru}(\mathrm{CO})$ complex is a particularly efficient catalyst for the carbene insertion to amine $\mathrm{N}-\mathrm{H}$ bonds. The reaction can be carried out under practical conditions: (i) a very low catalyst loading (0.05 mol\%); (ii) high starting amine concentration (1 M); (iii) 1.1 EDA eq. with respect to substrate and (iv) EDA can be added in one portion without need of slow 
addition by syringe pump. In contrast to many published catalysts, $\left[(\mathrm{BuO})_{8} \mathrm{Pc}\right] \mathrm{Ru}(\mathrm{CO})$ efficiently mediates the carbene insertion to amine under very high amine/catalyst ratio of 2000:1 showing no inactivation of the catalysts by strong amine coordination. A variety of aromatic, heterocyclic and aliphatic amines were selectively converted to substituted glycine derivatives with up to quantitative yields and turnover numbers achieving 2000. Of particular importance is the high selectivity of $\left[(\mathrm{BuO})_{8} \mathrm{Pc}\right] \mathrm{Ru}(\mathrm{CO})$ to single $\mathrm{N}-\mathrm{H}$ insertion even in the presence of 2-fold excess of EDA. In the previous study, $\mu$-carbido dimeric complex on the same ruthenium octabutylpthalocyanine platform could efficiently catalyzed $\mathrm{N}-\mathrm{H}$ amine insertion and cyclopropanation of olefins by EDA only at $90^{\circ} \mathrm{C}$. In addition, a mixture of single and double $\mathrm{N}-\mathrm{H}$ insertion was obtained. Interestingly, $\left[(\mathrm{BuO})_{8} \mathrm{Pc}\right] \mathrm{Ru}(\mathrm{CO})$ carried out cyclopropanation of aniline and $p$-methoxyaniline with higher trans/cis ratios of 4.8 and 7.3 compared with its $\mu$-carbido dimeric counterpart (2.3 and 3.0, respectively). Thus, $\left[(\mathrm{BuO})_{8} \mathrm{Pc}\right] \mathrm{Ru}(\mathrm{CO})$ exhibits a higher reactivity and selectivity in these carbene transfer reactions compared to its $\mu$-carbido binuclear congener providing an access to a wide scope of cyclopropane and glycine derivatives under practical reaction conditions.

\section{Experimental Section}

Ruthenium phthalocyanine complexes were prepared as previously described ${ }^{18 b, 26}$. Ethyl diazoacetatate containing 13 wt\% of dichloromethane was purchased from Sigma-Aldrich. Olefins and amines were obtained from Alfa Aesar or SigmaAldrich and were used as received.

The UV-vis spectra of ruthenium phthalocyanine solutions were recorded with Agilent 8453 diode-array spectrophotometer. ${ }^{1} \mathrm{H}$ and ${ }^{13} \mathrm{C}$ NMR spectra were acquired on a Bruker Avance HD spectrometer (400 Mhz). Samples were prepared in $\mathrm{CDCl}_{3}$ (Cambridge Isotope Laboratories, Inc.), which was filtered through a layer of alumina prior to use. NMR spectra were acquired at ambient temperature and were referenced to the solvent signals $\left(\mathrm{CHCl}_{3}\right.$ in the case of ${ }^{1} \mathrm{H}-\mathrm{NMR}$, $7.26 \mathrm{ppm}$ and ${ }^{13} \mathrm{CDCl}_{3}$ in the case of ${ }^{13} \mathrm{C}-\mathrm{NMR}, 77.16 \mathrm{ppm}$ ). The reaction products were identified by GC-MS technique (Hewlett Packard 5977B/7820A system; electron impact at $70 \mathrm{eV}, \mathrm{He}$ carrier gas, $30 \mathrm{~m} \times 0.25 \mathrm{~mm} \times 0.25 \mu \mathrm{m}$ HP-5MS U1 capillary column). High resolution mass spectra were obtained at Bruker QTOF Impact II spectrometer.

\section{Cyclopropanation of olefins}

All olefins were filtered through basic alumina and silica before use. A $2 \mathrm{M}$ solution of EDA in dichloromethane $(0.23 \mathrm{~mL}, 0.48$ $\mathrm{mmol}, 1.2$ eq.) was added to a solution of olefin ( $1 \mathrm{M}, 0.4 \mathrm{mmol}$, 1 eq.) and $\left[(\mathrm{BuO})_{8} \mathrm{Pc}\right] \mathrm{Ru}(\mathrm{CO})\left(1 \mathrm{mM}, 4.10^{-4} \mathrm{mmol}, 0.1 \mathrm{~mol} \%\right)$ in $0.4 \mathrm{~mL}$ of dichloromethane under argon by syringe pump over $2 \mathrm{~h}$ at $25^{\circ} \mathrm{C}$. The reaction mixture was magnetically stirred for 2,5 h. Reaction products were analyzed by ${ }^{1} \mathrm{H} N M R\left(\mathrm{CDCl}_{3}\right)$ using $\mathrm{CH}_{2} \mathrm{Br}_{2}$ as internal standard and GC-MS (See Supplementary Information). The products of several reactions were purified and isolated using PuriFlash XS 420 system (Interchim) at PF15SIHP flash columns (cyclohexane/ethyl acetate).

\section{Carbene $\mathrm{N}-\mathrm{H}$ insertion of amines}

EDA ( $91 \mu \mathrm{L}, 0.5 \mathrm{mmol}, 1,1 \mathrm{eq}$.) was added to a solution of amine (1 M, $0.5 \mathrm{mmol}, 1$ eq.) and $\left[(\mathrm{BuO})_{8} \mathrm{Pc}\right] \mathrm{Ru}(\mathrm{CO})\left(0.5 \mathrm{mM}, 2.5 .10^{-4}\right.$ $\mathrm{mmol}, 0.05 \mathrm{~mol} \%)$ in $0.5 \mathrm{~mL}$ of dichloromethane under argon atmosphere at $40^{\circ} \mathrm{C}$. The reaction mixture was magnetically stirred for $10 \mathrm{~min}-20 \mathrm{~h}$ at $40^{\circ} \mathrm{C}$. Reaction products were analyzed by ${ }^{1} \mathrm{H}$ NMR $\left(\mathrm{CDCl}_{3}\right)$ using $\mathrm{CH}_{2} \mathrm{Br}_{2}$ as internal standard and by GC-MS (See Supplementary Information). The products of several reactions were purified and isolated using Puriflash XS 420 system (Interchim) at PF-15SIHP flash columns (cyclohexane/ethyl acetate).

\section{Conflicts of interest}

There are no conflicts to declare.

\section{Acknowledgements}

This work was supported by Agence Nationale de Recherches, France (grant ANR-16-CE29-0018-01). AGM is grateful to the French Embassy in Moscow for financial support. LPG is indebted to Ministère de L'Education Nationale, de l'Enseignement Supérieur et de la Recherche, France for the PhD fellowship. Synthesis of catalysts was supported by the Ministry of Science and Higher Education of the Russian Federation, analytical mesurements were partially performed using equipment of CKP FMI IPCE RAS.

\section{Notes and references}

1 (a) A. Ford, H. Miel, A. Ring, C. N. Slattery, A. R. Maguire and M. A. McKervey, Chem. Rev., 2015, 115, 9981-10080; (b) C. Damiano, P. Sonzini and E. Gallo, Chem. Soc. Rev., 2020, 49, 4867-4905; (c) A. Caballero, M. M. Díaz-Requejo, M. R. Fructos, A. Olmos, J. Urbano and P. J. Pérez, Dalton Trans., 2015, 44, 20295-20307; (d) Y.-Y. Ren, S.-F. Zhu and Q.-L. Zhou, Org. Biomol. Chem., 2018, 16, 3087-3094; (e) L. Mertens and R. M. Koenigs, Org. Biomol. Chem., 2016, 14, 10547-10556; (f) C. Ebner and E. M. Carreira, Chem. Rev., 2017, 117, 1165111679; (g) K. J. Hock and R. M. Koenigs, Chem. Eur. J., 2018, 24, 10571-10583; (h) M. P. Doyle, R. Duffy, M. Ratnikov and L. Zhou, Chem. Rev., 2010, 110, 704-724; (i) H. M. L. Davis, J. Org. Chem., 2019, 84, 12722-12745; (j) S.-F. Zhu and Q.-L. Zhou, Acc. Chem. Res., 2012, 45, 1365-1377; (k) D. Gilligham and N. Fei, Chem. Soc. Rev., 2013, 42, 4918-4931; (I) H. Keipour, V. Carreras and T. Ollevier, Org. Biomol. Chem., 2017, 15, 54415456; (m) G. Simonneaux, P. Le Maux, Y. Ferrand and J. RaultBerthelot, Coord. Chem. Rev., 2006, 250, 2212-2221; (n) V.F. Batista, D. C. G. A. Pinto and A. M. S. Silva, ACS Catal., 2020, 10, 10096-10116; (o) V. Carreras, N. Tanbouza and T. Ollevier, Synthesis, 2020, 52, 10.1055/s-0040-1707272;

2 (a) G. R. Wolf, C. G. Hamaker, J.-P. Djukic, T. Kodadek and L. K. Woo, J. Am. Chem. Soc., 1995, 117, 9194-9199; (b) L. Nicolas, T. Roisnel, P. Le Maux and G. Simonneaux, Tetrahedron Lett., 2009, 50, 5149-5151; (c) Y. Li, J.-S. Huang, Z.-Y. Zhou, C.-M. Che and X.-Z. You, J. Am. Chem. Soc., 2002, 124, 13185-13193; (d) C. D. Du, B. Andrioletti, E. Rose and L. K. Woo, Organometallics, 2002, 21, 4490-4495; (e) Z. Gross, N. Galili and L. Simkhovich, Tetrahedron Lett., 1999, 40, 15711574; (f) D. M. Carminati, D. Intrieri, A. Caselli, S. Le Gag, B. 
Boitrel, L. Toma, L. Legrani and E. Gallo, Chem. Eur. J., 2016 22, 13599-13612; (g) B. Morandi, J. Cheang and E. M. Carreira, Org. Lett., 2011, 13, 3080-3081; (h) T.-S. Lai, F.-Y. Chan, P.-K. So, D.-L. Ma, K.-Y. Wong and C.-M. Che, Dalton Trans., 2006, 4845-4851; (i) A. Sarkar, D. Formenti, F. Ferretti, C. Kreyenschulte, S. Bartling, K. Junge, M. Beller and F. Ragani, Chem. Sci., 2020, 11, 6217-6221; (j) I. Aviv and Z. Gross, Chem. Commun., 2006, 4477-4479; (k) C. Empel, K. J. Hock and R. M. Koenigs, Org. Biomol. Chem., 2018, 16, 7129-7133; (I) $X$ Zhang, Z. Liu, X. Yang, Y. Dong, M. Virelli, G. Zanoni, E. A Anderson and X. Bi, Nat. Commun., 2019,10, 284; (m) H Wang, Q. Wan, K.-H. Low, C. Zhou, J.-S. Huang, J.-L. Zhang and C.-M. Che, Chem. Sci., 2020, 11, 2243-2259; (n) K. J. Hock, R. Spitzner and R. M. Koenigs, Green. Chem., 2017, 19, 21182122.

3 (a) B. J. Anding, T. O. Dairo and L. K. Woo, Organometallics, 2017, 36, 1842-1847; (b) B. J. Anding and L. K. Woo, Organometallics, 2013, 32, 2599-2607; (c) B. J. Anding, A. Ellern and L. K. Woo, Organometallics, 2012, 31, 3628-3635.

4 (a) K.-H. Chan, X. Guan, V. K.-Y. Lo and C.-M. Che, Angew. Chem., 2014, 126, 3026-3031; Angew. Chem. Int. Ed., 2014 53, 2982-2987; (b) C.-Y. Zhou, J.-S. Huang and C.-M. Che, Synlett, 2010, 2010, 2681-2700; (c) D. Intrieri, D. M. Carminati and E. Gallo, Dalton Trans., 2016, 45, 15746-15761; (d) E. Galardon, P. Le Maux and G. Simonneaux, Tetrahedron, 2000, 56, 615-621 ; (e) H.-X. Wang, Q. Wan, K. Wu, K.-H. Low, C. Yang, C.-Y. Zhou, J.-S. Huang and C.-M. Che, J. Am. Chem. Soc. 2019, 141, 9027-9046; (f) E. Galardon, P. Le Maux and G. Simonneaux, Chem. Commun., 1997, 927-928; (g) H. F. Srour, P. Le Maux, S. Chevance, D. Carrié, N. Le Yondre and G. Simonneaux, J. Mol. Catal. A: Chem., 2015, 407, 194-203.

5 C.-M. Che and J.-S. Huang, Coord. Chem. Rev., 2002, 231, 151164.

6 (a) C. F. Gorin, E. S. Beh, Q. M. Bui, G. R. Dirk and M. W. Kanan, J. Am. Chem. Soc., 2013, 135, 11257-11265; (b) K. Liao, T. C. Pickel, V. Boyarskikh, J. Bacsa, D. G. Musaev and H. M. L. Davies, Nature, 2017, 551, 609-613; (c) A. Homberg and J. Lacour, Chem. Sci., 2020, 11, 6362-6369; (d) D. Intrieri, A. Caselli and E. Gallo, Eur. J. Inorg. Chem., 2011, 5071-5081.

7 (a) Y. Chen and X. P. Zhang, J. Org. Chem., 2007, 72, 59315934; (b) Y. Chen, K. B. Fields and X. P. Zhang, J. Am. Chem. Soc., 2004, 126, 14718-14719; (c) M. Goswami, B. de Bruin and W. I. Dzik, Chem. Commun., 2017, 53, 4382-4385; (d) X. Xu, Y. Wang, X. Cui and L. Wojtas, X. P. Zhang, Chem. Sci. 2017, 8, 4347-4351; (e) Y. Wang, X. Wen, X. Cui and L. Wojtas, X. P. Zhang, J. Am. Chem. Soc., 2017, 139, 1049-1052; (f) L. Huang, Y. Chen, G.-Y. Gao and X. P. Zhang, J. Org. Chem., 2003 68, 8179-8184; (g) E. Gallo, E. Rose, B. Boitrel, L. Legnani and L. Toma, Organometallics, 2014, 33, 6081-6088.

8 D. Intrieri, D. M. Carminati and E. Gallo in Handbook of Porphyrin Science, Vol. 38, (Eds.: K. M. Kadish, K. M. Smith, R. Guilard), World Scientific, Singapore, 2016, pp. 1-99.

9 P. S. Coelho, E. M. Brustad, A. Kannan and F. H. Arnold, Science, 2013, 339, 307-310.

10 (a) O. F. Brandenberg, R. Fasan and F. H. Arnold, Curr. Opin. Biotechnol., 2017, 47, 102-111; (b) R. K. Zhang, X. Huang and F. H. Arnold, Curr. Opin. Chem. Biol., 2019, 49, 67-75; (c) Z. J. Wang, N. E. Peck, H. Renata and F. H. Arnold, Chem. Sci., 2014, 5, 598-601; (d) R. K. Zhang, K. Chen, X. Huang, L. Wohlschlager, H. Renata and F. H. Arnold, Nature, 2019, 565, 67-72; (e) V. Tyagi, R. B. Bonn and R. Fasan. Chem. Sci., 2015, 6, 2488-2494; (f) S. B. J. Kan, R. D. Lewis, K. Chen and F. H. Arnold, Science, 2016, 354, 1048-1051; (g) D. M. Carminati and R. Fasan, ACS Catal., 2019, 9, 9683-9697; (h) B. J. Wittmann, A. M. Knight, J. L. Hofstra, S. E. Reisman, S. B. J. Kan and F. H. Arnold, ACS Catal., 2020, 10, 7112-7116; (i) K. Chen and F. H. Arnold, J. Am. Chem. Soc., 2020, 142, 6891-6895.
11 P. Dydio, H. M. Key, A. Nazarenko, J. Y.-E. Rha, V. Seyedkazemi, D. S. Clark and J. F. Hartwig, Science, 2016, 354, 102-106.

12 Y. Gu, S. N. Natoli, Z. Liu, D. S. Clark and J. F. Hartwig, Angew. Chem., 2019, 131, 14092-14098; Angew. Chem. Int. Ed., 2019, 58, 13954-13960.

13 M. W. Wolf, D. A. Vargas and N. Lehnert, Inorg. Chem., 2017, 56, 5623-5635.

14 (a) B. Wang, I. G. Howard, J. W. Pope, E. D. Conte and Y. Deng, Chem. Sci., 2019, 10, 7958-7963; (b) Q.-C. Chen, I. Saltsman, A. Kaushansky, Z.-Y. Xiao, N. Fridman, X. Zhan and Z. Gross, Chem. Eur. J., 2018, 24, 17255-17261; (c) A. Chirila, B. G. Das, N. D. Paul and B. de Bruin, ChemCatChem, 2017, 9, 1413-1421; (d) A. Conde, G. Sabenya, M. Rodriguez, V. Postils, J. M. Luis, M. M. Diaz-Requejo, M. Costas and P. J. Pérez, Angew. Chem., 2016, 128, 6640-6644; Angew. Chem. Int. Ed., 2016, 55, 65306534.

15 (a) I. Aviv and Z. Gross, Chem.Eur. J., 2008, 14, 3995-4005; (b) I. Aviv and Z. Gross, Synlett, 2006, 951-953; (c) L. Simkhovich, A. Mahammed, I. Goldberg and Z. Gross, Chem.Eur. J., 2001, 7, 1041-1055; (d) Z. Gross, L. Simkhovich and N. Galili, Chem. Commun., 1999, 599-600.

16 (a) H.-H Liu, Y. Wang, Y.-J. Shu, X.-G. Zhou, J. Wu and S.-Y. Yan, J. Mol. Catal. A: Chem., 2006, 246, 49-52; (b) D. L. Ventura and R.W. Kubiak II, Tetrahedron Lett., 2014, 55, 2715-2717; (c) V. B. Sharma, S. L. Jain and B. Sain, Catal. Commun., 2006, 7, 454456; (d) J. R. Griffin, C. I. Wendell, J. A. Garwin and M. C. White, J. Am. Chem. Soc., 2017, 139, 13624-13627; (e) C. Empel, K. J. Hock and R. M. Koenigs, Chem. Commun., 2019, 55, 338-341.

17 L. P. Cailler, M. Clémancey, J. Barilone, P. Maldivi, J.-M. Latour and A. B. Sorokin, Inorg. Chem. 2020, 59, 1104-1116.

18 (a) L. P. Cailler, A. G. Martynov, Yu. G. Gorbunova, A. Yu. Tsivadze and A. B. Sorokin, J. Porphyrins Phthalocyanines 2019, 23, 497-506 ; (b) A. P. Kroitor, L. P. Cailler, A. G. Martynov, Yu. G. Gorbunova, A. Yu. Tsivadze and A. B. Sorokin, Dalton Trans., 2017, 46, 15651-15655.

19 I. Nicolas, P. Le Maux and G. Simonneaux, Tetrahedron Lett., 2008, 49, 5793-5795.

20 C.-M. Che, J.-S. Huang, F.-W. Lee, Y. Li, T.-S. Lai, H.-L. Kwong, P.-F. Teng, W-S. Lee, W.-C. Lo, S.-M. Peng and Z.-Y. Zhou, J. Am. Chem. Soc., 2001, 123, 4119-4129.

21 E. Galardon, P. Le Maux and G. Simonneaux, J. Chem. Soc. Perkin Trans. 1, 1997, 2455-2456.

22 C.-M. Ho, J.-L. Zhang, C.-Y. Zhou, O.-Y. Chan, J. J. Yan, F.-Y. Zhang, J.-S. Huang and C.-M. Che, J. Am. Chem. Soc., 2010, 132, 1886-1894.

23 G. Maas, Chem. Soc. Rev., 2004, 33, 183-190.

24 (a) A. B. Sorokin, Chem. Rev., 2013, 113, 8152-8191; (b) P. Afanasiev and A. B. Sorokin, Acc. Chem. Res. 2016, 49, 583593; (c) Ü. İşci, A. S. Faponle, P. Afanasiev, F. Albrieux, V. Briois, V. Ahsen, F. Dumoulin, A. B. Sorokin and S. P. De Visser, Chem. Sci., 2015, 6, 5063-5075; (d) M. G. Quesne, D. Senthilnathan, D. Singh, D. Kumar, P. Maldivi, A. B. Sorokin and S. P. de Visser, ACS Catal. 2016, 6, 2230-2243; (e) C. Colomban, E. V. Kudrik, P. Afanasiev, A. B. Sorokin, J. Am. Chem. Soc., 2014, 136, 11321-11330.

25 (a) E. A. Lukyanets and V. N. Nemykin, J. Porphyrins Phthalocyanines, 2010, 14, 1-40; (b) V. N. Nemykin and E. A. Lukyanets, ARKIVOC, 2010, 136-208.

26 A. P. Kroitor, A. G. Martynov, Y. G. Gorbunova, A. Yu. Tsivadze and A. B. Sorokin, Eur. J. Inorg. Chem. 2019, 1923-1931.

27 A. M. Rodríguez, F. Molina, M. M. Díaz-Requejo and P. J. Pérez, Adv. Synth. Catal., 2020, 362, 1998-2004.

28 J. S. Yadav, B. V. S. Reddy and G. Satheesh Tetrahedron Lett., 2003, 44, 8331-8334.

29 R. Li, D. S. Larsen and S. Brooker, New J. Chem., 2003, 27, 1353-1359.

30 L. K. Baumann, H. M. Mbuvi, G. Du and L. K. Woo, Organometallics, 2007, 26, 3995-4002. 